\title{
QUASI-FIDEISM AND SCEPTICAL FIDEISM
}

\author{
DUNCAN PRITCHARD \\ https:/ / orcid.org/0000-0002-5997-0752 \\ University of California Irvine \\ Department of Philosophy \\ Irvine, California \\ U.S.A. \\ dhpritch@uci.edu
}

\author{
Article info \\ CDD: 121.7 \\ Keywords \\ Quasi-Fideism \\ Skeptical Fideism \\ Scepticism \\ Epistemology \\ Religious Belief
}

Received: 23.04.2021; Accepted: 15.05.2021

https://doi.org/10.1590/0100-6045.2021.V44N4.DP

\begin{abstract}
My interest is in the relationship between the contemporary account of the epistemology of religious belief, known as quasi-fideism, and the sceptical fideism that has been so important, historically, in motivating fideistic ideas. I argue that we can profitably construe quasi-fideism along sceptical fideist lines, in that it is a proposal that is naturally understood as both arising within the context of a sceptical investigation and as exhibiting core features that it shares with Pyrrhonian scepticism. Moreover, I suggest that sceptical fideism, properly rendered, is inclined towards the kind of restricted fideism that is essential to quasifideism.
\end{abstract}

1. One of the enduring insights of Richard Popkin's (1965; 2003) magisterial work on the history of sceptical thought is 
the manner in which sceptical insights have been employed to bolster, rather than undermine, religious conviction. ${ }^{1}$ In particular, there is a certain fideistic tradition that employs Pyrrhonian sceptical techniques in defence of religious faith, and thereby in support of a fideistic treatment of such faith. ${ }^{2}$ The most notable exponent of this sceptical fideism is Montaigne, particularly in his Apology for Raymond Sebond, the text that Popkin $(2003,56)$ famously referred to as the 'womb of modern thought'.

In its broadest terms, we can think of sceptical fideism as a kind of extension of Pyrrhonian scepticism. Recall that the Pyrrhonian sceptical modes were only thought to be applicable to our theoretical commitments that we have some rational control over, with the result that our most natural and spontaneous commitments are thereby immune to sceptical doubt. One can't help but feel cold when one is faced with a frosty morning, and hence it would be irrelevant to submit such a response to sceptical scrutiny, in contrast to the kinds of theoretical claims that naturally feature in the crosshairs of sceptical investigation. As we might put it, in a Humean spirit, some of our most basic commitments are more the product of the passions rather than reason, and hence are not properly subject to rational evaluation.

One can think of the application of the Pyrrhonian sceptical modes as being a way of bringing these arational basic commitments to light, in that their very immunity to sceptical doubt sets them apart from other kinds of commitments that we have which can be undermined by the employment of sceptical techniques. This point is crucially relevant to sceptical fideism, for whereas for Pyrrhonism the realm of that which lies beyond the reach of sceptical doubt is very restricted (thereby raising the problem of how it is even possible to live a life of Pyrrhonian scepticism), Montaigne's innovation was to claim that the scope of what is resistant to sceptical doubt is much broader, and can even 
include religious conviction. ${ }^{3}$ Consider, for example, how Montaigne's thorough-going scepticism is used to highlight the arational nature of religious conviction. As he famously puts it, this conviction is 'like breathing', and as such needs no reasons. ${ }^{4}$ We thus arrive at an explanation of how scepticism, so often the enemy of religious belief, can be enlisted into its defence. What we need to recognise is that religious conviction, properly understood, is not within the realm of rational evaluation like our other commitments, and hence is not subject to it, any more than our other everyday, non-theoretical, commitments are.

The result is a way of defending religious faith that accounts for its certainty, but in a distinctively undogmatic fashion. Religious conviction is not to be understood as rooted in reasons, and hence it cannot be a form of certainty that extends beyond one's rational basis for it. But also, more importantly, the defence of religious conviction is embedded within a sceptical stance that exposes the limitations of reasons, and which thus leads to a kind of faith that is entwined with a wider intellectual humility. Here, for example, is how Brian Ribeiro describes Montaigne's approach:

"We need to renounce our wicked pride and become humble - we need a good humiliation, in the literal sense. And Pyrrhonism is the means to this end. By showing us how worthless our powers are, we will be stripped down and "made ready" to accept the "finger of God" without high-handed resistance. This pattern-Pyrrhonizing acid-bath followed by ready acceptance of faith-is what scholars now call fideistic skepticism, of which Christian Pyrrhonism (Montaigne's form) is a specific variant." (Ribeiro 2009, 13) 
The result is, in temperament at least, a moderate kind of religious faith, even while embracing the arational certainty at its heart. ${ }^{5}$

2. We can see the attraction of a specifically sceptical fideism by considering how fideism might fare without the sceptical motivation. In particular, imagine one's fideism being motivated by simply appealing to the very different kind of propositional attitudes, and associated epistemic practices, that are distinctive of the religious domain. One could then directly argue that these differences suffice to show that it is a mistake to think of religious conviction as being rationally assessable in the manner of ordinary non-religious belief. ${ }^{6}$ Such non-sceptical fideism would be in effect an insulation strategy in response to scepticism about the rationality of religious belief. The sceptic concerning the rationality of religious belief raises their challenge, and the non-sceptical fideist responds by insisting that religious conviction is not a kind of commitment that is subject to rational evaluation, and hence is immune to the sceptical challenge.

The obvious worry about such a strategy, however, is that it is in danger of looking ad hoc. In particular, what excludes the alternative diagnosis of the differences apparent in the religious domain, such that it is a domain that incorporates practices that are simply epistemically problematic? After all, the distinctive features of religious practices — such as, for example, the apparent immunity to counterevidence of its core commitments — can easily look to a critic of religion as indications that this is a form of belief riddled with epistemic vices, such as dogmatism.

Sceptical fideism seems to be on stronger ground in this regard, as it has a response to the ad hoc charge. The line of reasoning in play is, after all, perfectly general, and indeed even arises out of scepticism itself. This is that in showing 
that the basic commitments of a domain are impervious to the sceptical modes one thereby also reveals their essentially arational nature, and hence their immunity to scepticism. Sceptical fideism is thus not offering any special pleading on the part of the devout in trading on this strategy, but rather embracing the very restriction on the scope of sceptical doubt that is built into the Pyrrhonian stance, albeit in an extended form.

3. My interest here is in how the broad contours of the sceptical fideist position mesh with a contemporary proposal regarding the rationality of religious belief. This is the position that I have called quasi-fideism, a proposal that I think should be credited to the later Wittgenstein, particularly as outlined in his final notebooks, published as On Certainty. ${ }^{7}$ Quasi-fideism is to be distinguished from a straightforward fideism, of a kind that is usually attributed to the later Wittgenstein, whereby religious belief is to be understood along very different lines to ordinary belief by not being subject to rational evaluation. There is good reason for treating Wittgenstein as a straightforward fideist, in that this does seem to be the position he is advocating in some of his later work, especially in the material published as Wittgenstein's Lectures and Conversations on Aesthetics, Psychology and Religious Belief (1963). ${ }^{8}$ But I've elsewhere contended that a distinct position in this regard emerges in On Certainty, whereby the kind of hinge commitments that he explores there have direct application to the religious case. Indeed, I've further suggested that this is no accident, since one of the key influences on Wittgenstein's treatment of hinge commitments is John Henry Newman's work on the rationality of religious belief, especially in his Essay in Aid of a Grammar of Assent (Newman 1979 [1870]).9 As such, although religious concerns are not at the forefront of $\mathrm{On}$ 
Certainty, they are playing a considerable role behind the scenes, as they constitute part of the original impetus for the ideas being explored.

The guiding idea that Wittgenstein is exploring in $\mathrm{On}$ Certainty concerns the structure of rational evaluation, and in particular the distinctive role that a specific class of everyday certainties play in this regard. On a traditional conception of the structure of rational evaluation, there is no in principle limitation on the scope of rational evaluations. One can thus conceivably rationally evaluate all of one's commitments at once. This picture is shared by both radical sceptical and conventional anti-sceptical proposals - whereas the former attempts to rationally evaluate all of our commitments at once and find them wanting, the latter attempts the same rational evaluation but with a positive result. (Note that we are here discussing scepticism as a philosophical view, or paradox arising out of a philosophical view, rather than scepticism as a practice, which is how it appears in Pyrrhonism. We will be returning to this point). Wittgenstein argues, however, that this picture is fundamentally mistaken, and this is where the hinge commitments come in.

Our hinge commitments typically concern entirely mundane everyday claims that we are optimally certain of, such as that one has two hands (in normal circumstances), one's name is such-and-such, one has never been to the moon, one has parents, and so on. G. E. Moore (1925; 1939) had previously alerted us to the special kind of certainty that attaches to these everyday claims (as, indeed, had Newman previously), but his aim had been to contend that this certainty provides a kind of commonsense rational basis for pushing back against revisionist philosophical proposals like idealism. ${ }^{10}$ Wittgenstein, in contrast, draws a very different moral, which is that these optimal certainties are in fact completely rationally groundless. They are, instead, manifestations of an overarching certainty that needs to be 
in place in order for the very practice of rational evaluation to be possible — as he puts it, they are the 'hinges' on which the 'door' of rational evaluation turns. (OC, $\int \$ 341-43$ ) This is why our hinge commitments are not themselves subject to rational evaluation. A very different conception of the structure of rational evaluation thus emerges, one on which there are in principle constraints on the scope of such evaluations, since they cannot extend so far as to take in one's hinge commitments.

In support of this alternative picture, Wittgenstein tries to get us to see how unusual these hinge commitments are, despite their apparent mundanity. He highlights the unusual way that they are acquired, such that they are presupposed in the claims that one is taught- 'swallowed down' (OC, \$143), as he memorably puts it - rather than being explicitly taught. No-one teaches you that you have hands, for example, but rather to do things with your hands (e.g., OC, \$374). Relatedly, we are not normally aware of the special role that these commitments play in our rational practices, since the question of their rational standing simply never arises in normal conditions. As Wittgenstein (OC, \$88) puts it, they "lie apart from the route travelled by inquiry." This is the sense in which our hinge commitments are hidden in plain view, in that it takes an unusual context of inquiry - usually of a sceptical, and thus philosophical nature- to bring the nature of these commitments to light.

Our hinge commitments bear an unusual relationship to reasons, in that their certainty is not only not grounded in reasons, but is also unresponsive to them. This is because we undertake rational evaluations by keeping these certainties fixed-if, in normal conditions, one didn't see one's hands where one expects to see them, then that would be a reason to doubt one's eyesight rather than a reason to doubt whether one has hands. (OC \$125, \$250). Our hinge certainty is manifest in our actions, which is why Wittgenstein (OC, 
\$342) argues that they are "in deed not doubted." One might say that one doubts them, or act as if one doubts them, but in reality there is no genuine doubt, as is manifest from one's actions (e.g., that one continues to act in a way that presupposes the existence of one's hands). ${ }^{11}$ Our hinge certainty, as Wittgenstein (OC, \359, \$475, \$559) expresses it, is 'animal', 'primitive'; it is there 'like our life'.

Since our hinge commitments are not rationally grounded, they cannot amount to knowledge. It would be misleading, however, to simply describe them as unknown, as in an important sense they are neither known nor unknown, since they are simply not in the market for knowledge in the first place. It is not as if, for example, our lack of knowledge of our hinge commitments indicates ignorance on our parts, as if this is something that we could have known, if only we had been smarter or more attentive. ${ }^{12}$ We should thus not lament our failure to know these propositions, since to aspire to know them is akin to aspiring to being able to draw a circle-square.

4. The distinctive nature of our hinge commitments means that they are not like our ordinary beliefs. The quotidian notion of belief is notoriously broad, and can cover a wide range of propositional attitudes-essentially any propositional attitude that involves a general endorsement of the target proposition - which means that our ordinary beliefs and our hinge commitments, despite their important differences, can both plausibly fall under the same heading. ${ }^{13}$ With that in mind, it is worth delineating a narrower notion of belief that is of particular relevance to epistemology—viz; that propositional attitude that is a constituent part of rationally grounded knowledge. Call this $K$-apt belief. $\mathrm{K}$-apt belief is very different to a hinge commitment on account of its basic conceptual connections to reasons and truth. In 
particular, we can highlight one key aspect of K-apt belief that is inapplicable to a hinge commitment, which is that a $\mathrm{K}$-apt belief that $p$ cannot survive the explicit recognition that one has no rational basis for the truth of $p$. To continue being committed to the truth of $p$ even once a lack of a rational basis for the truth of $p$ has been recognised is to have a very different kind of propositional attitude to $p$, such as a wishful thinking that $p$, or a hoping that $p$. Interestingly, however, it is part of the nature of our hinge commitments that one's certainty in their truth continues even once one recognises that one has no rational basis for this certainty, since it is not a conviction that is either grounded in, or responsive to, rational considerations. Hinge commitments thus fail this test for K-apt belief, and hence are not beliefs in this sense. ${ }^{14}$

5. While Wittgenstein doesn't himself articulate in any detail how this conception of the structure rational evaluation might be relevant to one's religious commitments, it does seem to have a fairly direct application in this regard. For isn't a religious believer's fundamental religious conviction also a hinge commitment? It certainly has many of the core characteristics. It is optimally certain. It plays a presuppositional role in the structure of the subject's religious commitments. And it acts like a fulcrum in the subject's system of rational evaluation, such that it is a fixed point relative to which other claims are rationally assessed. Relatedly, basic religious conviction doesn't seem to be a Kapt believing either, but is instead better captured as a propositional attitude, like that of a hinge commitment, that bears a fundamentally different relationship to reasons. ${ }^{15}$

Thus far casting one's basic religious convictions as hinge commitments seems to suggest a straightforward fideism, whereby such conviction is to be understood in a distinct 
way from ordinary believing, and hence not subject to rational assessment as our ordinary believing is. What makes the proposal quasi-fideistic, however, are two key, and interrelated, features of the view.

The first is that traditional forms of fideism exclude religious belief in general from rational evaluation, while quasi-fideism only treats one's most fundamental religious certainties as hinge commitments-one's other religious beliefs, such as one's theological commitments, can be K-apt beliefs in the usual way. This helps to avoid a core problem that afflicts straightforward forms of fideism, which concerns how many religious commitments seem to be akin to ordinary beliefs and hence rationally evaluable in the usual way, even if the most fundamental religious commitments are not like this. What about doctrinal disputes, for example? How would we even make sense of such disagreements on a straightforward fideistic model whereby religious belief is not within the realm of rational evaluation? Relatedly, isn't the process of convincing others about theological questions an essentially rational matter? This suggests that a distinction needs to be drawn between a subject's fundamental religious convictions, which are to be construed as falling within the realm of fideism, and her more peripheral religious beliefs, such as concerning theological matters, which do not. That picture clearly favors quasi-fideism over a straightforward fideism that simply exempts all religious commitments from rational evaluation.

The second is that a straightforward form of fideism proceeds by distinguishing the religious domain from ordinary non-religious domains, and thereby treating the beliefs associated with the former domain as being exempt from rational evaluation, unlike the latter. In contrast, quasifideism proceeds by arguing that religious conviction is no different in kind to ordinary non-religious conviction. In both cases one's K-apt believing presupposes that specific 
arational hinge commitments are play. The religious domain is thus no different from the non-religious domain.

This second point is crucial to understanding the kind of parity argument that can be pitted by the quasi-fideist against a specific form of scepticism that targeted the rationality of religious belief. ${ }^{16}$ One might naturally argue that the fact that religious belief involves basic arational commitments on the part of the subject is a count against the rationality of religious belief. But if it is just as true of ordinary belief that it also has basic arational commitments at its core, then there can't be anything specifically epistemically amiss with religious belief on this score. In particular, so long as we apply the same epistemic standards to our assessment of religious belief as we do to everyday non-religious belief, as epistemic parity demands, then religious belief is on a par, epistemically speaking, with ordinary non-religious belief.

This point about epistemic parity relates to a key advantage that quasi-fideism has over a straightforward fideism. One charge that is often levelled at the latter is that it effectively ghettoizes religious belief by uniquely making it immune to rational assessment, in contrast to belief in general. Quasi-fideism, in contrast, involves no such ghettoization, as the system of epistemic evaluation that is applicable to religious belief is exactly the same as that which is applicable to belief in general.

6. The manner in which quasi-fideism avoids the epistemic ghettoization of religious belief is crucial to understanding how it can be aligned with sceptical fideism. The key is to appreciate how the anti-sceptical import of our hinge commitments (whether religious or otherwise) arises in the context of a sceptical investigation of everyday certainties, whereby we become aware of their arational nature, since ordinarily their hinge status is hidden from us (albeit in plain 
view). In discovering the special role that they play in our epistemic practices, however, one thereby comes to appreciate why they are themselves immune to rational evaluation. Crucially, what applies to hinge commitments in general in this regard also applies to specific religious hinge commitments.

This sceptical feature of quasi-fideism has two important consequences. The first is that the defence of religious conviction does not treat it in any way differently from ordinary non-religious belief. Just as it is sceptical investigation that exposes the fundamental arational commitments at the heart of ordinary non-religious belief, so it also exposes the fundamental arational commitments at the heart of religious belief too. The second is that these sceptical investigations only highlight the arational nature of one's fundamental commitments, whether religious or nonreligious, and hence do not lead to treating religious belief in general as being immune to rational evaluation. Putting both points together, there is thus no ghettoization of religious belief since (i) the domain of religious commitment is not being treated any differently from ordinary non-religious domains, and (ii) non-fundamental religious belief is in any case on this view subject to rational evaluation in the usual way.

7. Conceiving of quasi-fideism as a form of sceptical fideism requires us to specify the extent to which this approach manifests a sceptical drive. After all, in contrast to Montaigne, there is no explicit appeal to Pyrrhonian sceptical techniques in Wittgenstein's work. Nonetheless, there does seem to be an implicit appeal to Pyrrhonian sceptical themes in Wittgenstein's writings, as a number of commentators have pointed out. ${ }^{17}$ 
This is especially evident in the quietistic approach Wittgenstein takes to philosophical problems, along with the associated lack of scepticism he has regarding our ordinary practices (i.e., such that they do not stand in need of a philosophical defence). Like Pyrrhonism, Wittgenstein treats philosophy as a practice rather than being aimed at established a body of philosophical doctrine, where that practice is concerned with unpicking the faulty theoretical pictures that philosophy generates of our ordinary practices, pictures which in turn generate illusory philosophical problems. So construed, the quietistic practice of philosophy can be thought of as embodying a kind of thorough-going scepticism about theory, which provides at least one overlap with classical Pyrrhonism. ${ }^{18}$

In the literature on Wittgenstein's thought, his quietism is most associated with his Philosophical Investigations (1953), but as I have argued elsewhere, one can just as much find this approach on display in his remarks on hinge commitments. ${ }^{19}$ Our ordinary practices of rational evaluation, properly described, do not license the philosophical picture that generates radical scepticism, whereby there is no in principle constraint on the scope of rational evaluation, and hence universal rational evaluations are entirely coherent. Instead, reflecting on the nature of these practices reveals the essential role that hinge commitments play in those practices. This is why the problem of radical scepticism is illusory, since it trades upon a dubious theoretical picture masquerading as commonsense. Once that picture is shown to be distinct from what our ordinary practices in fact involve, then radical scepticism is revealed as not arising out of a fundamental tension in those practices at all, but is instead the result of faulty philosophical theorizing. Rather than licensing the universal rational evaluations at issue in both radical 
scepticism and traditional responses to radical scepticism, our ordinary practices in fact preclude such evaluations.

We thus see the sceptical Wittgenstein practice of philosophical engagement undoing the theoretical errors embodied in a faulty philosophical picture, and in the process revealing that our ordinary practices were never problematic in the way alleged. The scope of reason has been shown to be less extensive than was hitherto supposed, at least by philosophers, albeit in a fashion that leaves our ordinary practices entirely intact. For Wittgenstein, as for the Pyrrhonians, it is not our ordinary practices, unreflectively understood, that are the proper objects for sceptical attack, but rather the theoretical stance that attempts to go beyond such ordinary practices, and thereby either externally ground those practices or else find them wanting on account of the absence of an external grounding. The upshot is that a Wittgensteinian line on hinge commitments, just like Montaigne's defence of religious conviction, can both defend the legitimacy of arational certainties while also setting that defence within a wider stance of intellectual humility.

It is worth highlighting here the distinction, already previously noted in outline, between the lived sceptical practices that we find manifest in Pyrrhonism and, to a certain extent at least, in Wittgenstein's later writings, and the radical scepticism that is a target for Wittgenstein's quietism in $O n$ Certainty. These two forms of scepticism are very different. Whereas the former attacks theoretical claims, the latter is itself part of a philosophical, and thus theoretical, picture. We can bring this point into sharper relief by reiterating that Wittgenstein's critique of this picture undermines both radical scepticism and traditional responses to radical scepticism, since they both presuppose it. This is the sense in which Wittgenstein's dissolution of the problem of radical scepticism is a kind of sceptical solution, since it 
rejects standard forms of anti-scepticism, as they also buy into the theoretical picture that Wittgenstein eschews. ${ }^{20}$

With these points in mind, it should be clear how the Wittgensteinian treatment of hinge commitments could be aligned with a sceptical fideism when applied to the religious case. For it is in applying this sceptical practice to a certain theoretical picture that one is led to a view on which fundamental religious commitments can be in their nature arationally held and, thereby, immune to rational evaluation. In particular, the initial motivation for fideism is arising out of sceptical practices, in terms of the hinge commitments becoming manifest as a result of a sceptical investigation into their rational standing. Moreover, the very conception of hinge commitments that is offered in response to those sceptical investigations represents a kind of Pyrrhonian sceptical practice, to the extent that it targets our theoretical commitments but leaves our everyday practices alone.

8. We have seen how quasi-fideism can be reconstrued as a form of sceptical fideism. Could the direction of fit go the other way as well? I think there are positive considerations for taking this possibility seriously, at least to the extent that sceptical fideism is best understood as exempting only our most fundamental religious commitments from rational evaluation, and not our religious commitments en masse. We have already noted the awkwardness of casting the fideist net so wide that it excludes all of a subject's religious commitments from rational evaluation, given that many of these commitments seem to function just like ordinary beliefs. This observation lends support to the more restricted strategy employed by quasi-fideism, where only the subject's most fundamental religious convictions are excluded from rational evaluation. 
With this distinction in mind, let us return to consider our historical paradigm when it comes to sceptical fideism, Montaigne. A key move that Montaigne makes when it comes to his defence of religious commitment is to appeal to how the deliverances of custom, and thus religious custom, can be immune to sceptical attack. ${ }^{21}$ There is a clear precedence for this stance in Pyrrhonian skeptical thought, as Sextus Empiricus famously maintains that commitments that are the result of custom can be immune to the application of the sceptical modes. ${ }^{22}$ One can see the attraction of the idea, in that deeply ingrained customs can make certain kinds of commitments so second-nature that they are as spontaneous and immune to reasons as one's immediate sensory judgements.

Crucially, however, not all of one's custom-based beliefs are like this, as many can be subject to rational evaluation in the normal way (and ought to be), as when someone grows up and starts to question the beliefs that she was raised up with. We thus do not want to insulate customary beliefs from sceptical scrutiny on a wholesale basis. Instead, what we are after is a distinction between a core set of fundamental commitments that are immune to rational evaluation and a peripheral set of commitments that are subject to the sceptical modes in the usual way. In short, custom can be a way of ingraining commitments so fiercely that they are then more the product of the passions than of reason, but it need not always be so.

This issue bears on religious belief because of the role of the customs in this regard. One is inculcated into a religious practice, after all. Such customs can lead to fundamental religious convictions that are akin to breathing, to use Montaigne's suggestive analogy, where arguments about their status make no sense. But these customs can also lead to religious (K-apt) beliefs, of a kind that would be properly subject to, say, doctrinal disputes, and here rational 
evaluation would clearly be applicable. The innovation of Montaigne is to highlight how religious conviction can fall into the class of custom-based beliefs that are immune to rational evaluation, where this is highlighted by the application of the Pyrrhonian sceptical modes. In this way, scepticism doesn't undermine religious conviction, but rather demonstrates that, at root, it does not fall within the purview of sceptical arguments. Relatedly, the application of such techniques also highlights to us which of our religious commitments fall under the fideistic heading and which are to be subject to doubt in the usual way, for the test is whether they are impervious to the sceptical modes. If we apply this strategy carefully, however, then we will be led to a quasifideistic line which only exempts our most fundamental religious commitments from rational scrutiny, and not a straightforward fideism that excludes religious commitments from rational evaluation en masse. We thus find that sceptical fideism, properly understood, begins to converge on quasifideism.

9. I have argued that quasi-fideism is best thought of as a form of sceptical fideism, in that it both arises in the context of a sceptical investigation and also represents a response to the challenge that this investigation raises that is essentially Pyrrhonian in spirit. Moreover, I have further suggested that sceptical fideism, properly understood, may well naturally end up endorsing a key element of quasi-fideism.

\section{References}

Alston, W. P. (1982). 'Religious Experience and Religious Belief', Noûs 16, 3-12.

— (1986). 'Is Religious Belief Rational?', The Life of 
Religion, (ed.) S. M. Harrison \& R. C. Taylor, 1-15, Lanham, Maryland: University Press of America.

— (1991). Perceiving God: The Epistemology of Religious Experience, Cornell, Ithaca: Cornell University Press.

— (1996). 'Belief, Acceptance, and Religious Faith', Faith, Freedom, and Rationality: Philosophy of Religion Today, (eds.) J. Jordan \& D. Howard-Snyder, 3-27, Lanham, MD: Rowman \& Littlefield.

Amesbury, R. (2016). 'Fideism', Stanford Encyclopedia of Philosophy, (ed.) E. Zalta, https://plato.stanford.edu/entries/fideism/.

Annas, J. (2012). 'Ancient Scepticism and Ancient Religion', Episteme, etc.: Essays in Honour of Jonathan Barnes, (eds.) B. Morison \& K. Ierodiakonou, ch. 4, Oxford: Oxford University Press.

Annas, J., \& Barnes, J. (tr.) (2000). Sextus Empiricus: Outlines of Scepticism, Cambridge: Cambridge University Press.

Audi, R. (1991). 'Faith, Belief, Rationality', Pbilosophical Perspectives 5, 213-39.

Bailey, A. (2002). Sextus Empiricus and Pyrrbonian Scepticism, Oxford: Oxford University Press.

Barnes, J. (1997). 'The Beliefs of a Pyrrhonist', The Original Sceptics: A Controversy, (eds.) M. Burnyeat \& M. Frede, 58-91, Indianapolis, IN: Hackett Publishing.

Barrett, C. (1997). 'Newman and Wittgenstein on the Rationality of Religious Belief, Newman and Conversion, (ed.) I. Ker, 89-99, Notre Dame, Indiana: Notre Dame University Press.

Bennett-Hunter, G. (2019). 'Wittgensteinian Quasi-Fideism and Interreligious Communication', Interpreting 
Interreligious Relations with Wittgenstein: Philosophy, Theology and Religious Studies, (eds.) G. Andrejč \&D. H. Weiss, 157-73, Leiden, Netherlands: Brill.

Bell, R. H. (1995). 'Religion and Wittgenstein's Legacy: Beyond Fideism and Language Games', Philosophy and the Grammar of Religious Belief, (eds.) T. Tessin \& M. von der Ruhr, 215-48, London: Palgrave Macmillan.

Cardoso, S. (2010). 'On Skeptical Fideism in Montaigne's Apology for Raymond Sebond, Skepticism in the Modern Age: Building on the Work of Richard Popkin, (eds.) J. M. Neto, G. Paganini \& J. C. Laursen 71-82, Leiden, Holland: Brill.

Coliva, A. (2010). Moore and Wittgenstein: Scepticism, Certainty, and Common Sense, London: Palgrave Macmillan.

- (2015). Extended Rationality: A Hinge Epistemology, London: Palgrave Macmillan.

di Ceglie, R. (2017). 'Faith and Reason: A Response to Duncan Pritchard,' Philosophy 92, 231-47.

de Ridder, J. (2019). 'Against Quasi-Fideism', Faith and Philosophy 36, 223-43.

Gascoigne, N. (2019). Rorty, Liberal Democracy, and Religious Certainty, London: Bloomsbury.

Gutschmidt, R. (2020). 'Beyond Quietism. Transformative Experience in Pyrrhonism and Wittgenstein', International Journal for the Study of Skepticism 10, 105-28. Howard-Snyder, D. (2016). 'Does Faith Entail Belief?', Faith and Philosophy 33, 142-62.

Kienzler, W. (2006). 'Wittgenstein and John Henry Newman on Certainty', Grazer Philosophische Studien 71, 117-138.

McDowell, J. (2009). 'Wittgenstein's 'Quietism”, Common Knowledge 15, 365-72.

McGinn, M. (1989). Sense and Certainty: A Dissolution of Scepticism, Oxford: Blackwell. 
Moore, G. E. (1925). 'A Defence of Common Sense', Contemporary British Philosophy (2 ${ }^{\text {nd }}$ series), J. (ed.) H. Muirhead, London: Allen \& Unwin.

- (1939). 'Proof of an External World', Proceedings of the British Academy 25, 273-300.

Moyal-Sharrock, D. (2004). Understanding Wittgenstein's On Certainty, London: Palgrave Macmillan.

Newman, J. H. (1979 [1870]). An Essay in Aid of a Grammar of Assent, Notre Dame, IN: University of Notre Dame Press.

Nielsen, K. (1967). 'Wittgensteinian Fideism', Philosophy 42, 237-54.

Penelhum, T. (1983a). God and Scepticism: A Study in Scepticism and Fideism, Dordrecht, Holland: D. Reidel.

- (1983b). 'Scepticism and Fideism', The Skeptical Tradition, (ed.) M. Burnyeat, Berkeley, CA: University of California Press.

Phillips, D. Z. (1976). Religion Without Explanation, Oxford: Oxford University Press.

Plantinga, A. (1983). 'Reason and Belief in God', Faith and Rationality: Reason and Belief in God, (ed.) A. Plantinga \& N. Wolterstorff, 16-93, Notre Dame, Indiana: University of Notre Dame Press.

— (2000). Warranted Christian Belief, New York: Oxford University Press.

Pojman, L. (1986). 'Faith Without Belief?', Faith and Philosophy 3, 157-76.

Popkin, R. (1965). 'The High Road to Pyrrhonism', American Philosophical Quarterly 2, 18-32.

— (1992). 'Fideism, Quietism, and Unbelief: Skepticism For and Against Religion in the Seventeenth and Eighteenth Centuries', Faith, Reason, and Skepticism, 
(ed.) M. Hester, ch. 4, Philadelphia, PA: Temple University Press.

— (2003). The History of Scepticism from Savonarola to Bayle, New York: Oxford University Press.

Pritchard, D. H. (2011a). 'Wittgensteinian Quasi-Fideism', Oxford Studies in the Philosophy of Religion 4, 145-59.

- (2011b). 'Wittgenstein on Scepticism', Oxford Handbook on Wittgenstein, (eds.) O. Kuusela \& M. McGinn, 521-47, Oxford: Oxford University Press.

- (2015a). Epistemic Angst: Radical Skepticism and the Groundlessness of Our Believing, Princeton, NJ: Princeton University Press.

- (2015b). 'Wittgenstein on Faith and Reason: The Influence of Newman', God, Truth and Other Enigmas, (ed.) M. Szatkowski, 141-64, Berlin: Walter de Gruyter.

_ (2017a). 'Faith and Reason', Philosophy 81, 101-18.

- (2017b). 'Wittgenstein on Hinge Commitments and Radical Scepticism in On Certainty', Blackwell Companion to Wittgenstein, (eds.) H.-J. Glock \&J. Hyman, 563-75, Oxford: Blackwell.

- (2018). 'Quasi-Fideism and Religious Conviction', European Journal for Philosophy of Religion 10, 51-66.

- (2019a). Wittgensteinian Epistemology, Epistemic Vertigo, and Pyrrhonian Scepticism', Epistemology After Sextus Empiricus, J. Vlasits \& K. M. Vogt, 172-92, Oxford: Oxford University Press.

— (2019b). 'Wittgenstein's On Certainty as Pyrrhonism in Action', Wittgensteinian (adj.): Looking at Things from the Viewpoint of Wittgenstein's Philosophy, (eds.) N. de Costa \& S. Wuppuluri, 91-106, Dordrecht, Holland: Springer.

- (2021a). 'Ignorance and Inquiry', American Philosophical Quarterly 58, 111-23. 
- (2021b). 'Scepticism and Certainty: Moore and Wittgenstein on Commonsense and Philosophy', Cambridge Companion to Common Sense Philosophy, (eds.) R. Peels \& R. van Woudenberg, 247-64, Cambridge: Cambridge University Press.

— (Forthcominga). 'Exploring Quasi-Fideism', Hinge Epistemology, (eds.) D. Moyal-Sharrock \& C. Sandis, London: Anthem.

- (Forthcomingb). 'Pyrrhonism and Wittgensteinian Quietism, Ancient Scepticism and Contemporary Philosophy, (eds.) L. Perissinotto \& B. R. Cámara, Milan, Italy: Mimesis International.

Ribeiro, B. (2009). 'Sextus, Montaigne, Hume: Exercises in Skeptical Cartography', The Modern Schoolman, 87, 7-34.

- (Forthcoming), Sextus, Montaigne, Hume: Pyrrbonizers, Leiden, Holland: Brill.

Schönbaumsfeld, G. (2016). The Illusion of Doubt, Oxford: Oxford University Press.

Sluga, H. (2004). 'Wittgenstein and Pyrrhonism', Pyrrhonian Skepticism, (ed.) W. Sinnott-Armstrong, 99-117, Oxford: Oxford University Press.

Strawson, P. F. (1985). Skepticism and Naturalism: Some Varieties, New York: Columbia University Press.

Stump, E. (1986). 'Penelhum on Skeptics and Fideists', Synthese 67, 147-54.

Williams, M. (1991). Unnatural Doubts: Epistemological Realism and the Basis of Scepticism, Oxford: Blackwell.

Wittgenstein, L. (1922). Tractatus Logico-Philosophicus, (tr.) C. K. Ogden \& F. Ramsey, London: Kegan Paul.

— (1953). Philosophical Investigations, (eds.) G. E. M. Anscombe \& R. Rhees, (tr.) G. E. M. Anscombe, Oxford: Blackwell.

- (1966). Wittgenstein's Lectures and Conversations on 
Aesthetics, Psychology and Religious Belief, (ed.) C. Barrett, Oxford: Basil Blackwell.

— (1969). On Certainty, (eds.) G. E. M. Anscombe \& G. H. von Wright, (tr.) D. Paul \& G. E. M. Anscombe, Oxford: Blackwell.

Wolterstorff, N. (1983). 'Can Belief in God be Rational if it has no Foundations?’ Faith and Rationality: Reason and Belief in God, 135-86, (ed.) A. Plantinga \& $\mathrm{N}$. Wolterstorff, 16-93, Notre Dame, Indiana: University of Notre Dame Press.

Wright, C. (2004). 'Warrant for Nothing (and Foundations for Free)?', Proceedings of the Aristotelian Society (supp. vol.) $78,167-212$.

\section{Notes}

1 See also Penelhum (1983a; 1983b), who also draws on Popkin's work to defend sceptical fideism. For critical discussion of Penelhum's views, see Stump (1983).

2 For a useful overview of the history of fideistic thoughtone that puts sceptical fideism center-stage- see Amesbury (2016).

3 It should be noted that Sextus Empiricus also considers the possibility that religious conviction could be excluded from sceptical doubt. Consider these two passages (both translations from Annas \& Barnes 2000):

"By the handing down of customs and laws, we accept, from an everyday point of view, that piety is good and impiety bad." (PH I 24)

"Following ordinary life without opinions, we say that there are gods and we are pious 
towards the gods and say that they are provident [...].” (PH III 2)

The problem, however, is that given Sextus's wider remarks about religious dogma, the most natural interpretation of these passages is that the Pyrrhonist is merely 'going along with' religious belief, and not actually endorsing the content of those commitments herself. If correct, that would suffice to differentiate Sextus Empiricus's stance on these matters with that advocated by Montaigne. For further discussion of Sextus Empiricus in this regard, see Bailey $(2002,193)$ and Annas (2012). See also the 'rustic Pyrrhonist' line described by Barnes $(1997,85)$.

4 For an excellent recent discussion of Montaigne as employing the Pyrrhonian sceptical modes to this effect, see Ribeiro (forthcoming). See also Ribeiro (2009) and Cardoso (2010).

${ }^{5}$ In this respect there is a marked difference in tone between Catholic sceptical fideists like Montaigne and Protestant sceptical fideists like Pascal. Penelhum (1983a, 15-16) describes this as a contrast between a 'conformist fideism' that identifies faith with loyalty to a tradition, and an 'evangelical fideism.' See also Popkin $(1992,192)$.

6 As we note below, this is essentially how Wittgenstein (1966) is often thought to be motivating his variety of fideism, whereby religion represents a distinct form of life, one that has its own distinctive logic. As we will see below, however, in later work he came to advance a variety of fideism that was more sceptical in orientation. For critical discussion of the possibility of a Wittgensteinian (nonsceptical) fideism, see Nielsen (1967), Philips (1976), and Bell (1995).

7 Wittgenstein (1969). Henceforth: 'OC'. For the main defences of quasi-fideism, see Pritchard (2011a; 2015b; 
$2017 a ; 2018 c$; forthcominga). For some recent critical discussions of quasi-fideism, see di Ceglie (2017), BennettHunter (2019), de Ridder (2019), and Gascoigne (2019, passim).

8 For critical discussion of a straightforward fideistic reading of the later Wittgenstein, see Nielsen (1967), Philips (1976), and Bell (1995).

9 See, especially, Pritchard (2015b). For further discussion of the influence of Newman on Wittgenstein in this respect, see also Kienzler (2006) and Barrett (1997).

10 For further discussion of Moore's commonsense stance in this regard, and how it contrasts with Wittgenstein's treatment of hinge commitments, see Pritchard (2021b).

11 Though one's hinge commitments can change over time, and hence a proposition that was once an indubitable hinge commitment can become a regular belief that is rationally doubted by the subject—we will come back to this point.

12 As this remark indicates, I depart from the main contemporary accounts of ignorance by claiming that lack of knowledge does not suffice for ignorance. See Pritchard (2021a).

13 See Stevenson (2002) for a useful taxonomy of different notions of belief.

14 I discuss the kind of propositional attitude involved in our hinge commitments in more detail in Pritchard (2015a, part 2 ), where I also discuss the relevance of this notion for the problem of radical scepticism. As I explain, as a propositional attitude it is sui generis, but that doesn't prevent us from articulating its general structure, and moreover articulating how it is different from other propositional attitudes that are in the vicinity, such as acceptance, supposition, assumption, trusting, and so on. For some of 
the other key works that offer epistemological proposals that are inspired by Wittgenstein's account of hinge commitments, see Strawson (1985), McGinn (1989), Williams (1991), Wright (2004), Coliva (2010; 2015), and Schönbaumsfeld (2016). For two surveys of this literature, see Pritchard $(2011 b ; 2017 b)$.

15 There is a lively philosophical discussion of the relationship between faith and belief, and in particular concerning whether the former entails the latter. Given that quasi-fideism treats religious hinge commitments as beliefs in the folk sense (albeit not in the K-apt sense), it is thus incompatible with a fictionalist account of fundamental religious conviction, whereby religious conviction doesn't involve a literal commitment to particular religious truths. For some of the key contemporary discussions of faith and belief in this regard, see Pojman (1986), Audi (1991), Alston (1996), and Howard-Snyder (2016).

16 The notion of a parity argument in this regard is usually associated with contemporary reformed epistemology, whereby the epistemic status of basic religious belief is defended by showing how it is akin to basic forms of belief of other kinds which are not thought to be epistemically problematic, such as perceptual belief. For some of the key defences of reformed epistemology, see Alston (1982; 1986; 1991), Plantinga (1983; 2000), and Wolterstorff (1983).

17 Wittgenstein was especially influenced by the AustroHungarian intellectual Fritz Mauthner, who adopted a distinctive kind of Pyrrhonism. (Mauthner receives the rare honour of being mentioned by Wittgenstein in the Tractatus_-see Wittgenstein (1922, \4.0031)). For a very useful discussion of the influence of Mauthner's work on Wittgenstein, see Sluga (2004). I discuss the Pyrrhonian themes in Wittgenstein's discussion of hinge commitments 
in Pritchard (2019a; 2019b; forthcomingb). See also Gutschmidt (2020).

18 For further discussion of the overlaps between Wittgenstein's quietism and Pyrrhonian scepticism, see Pritchard (2019a; 2019b; forthcomingb) and Gutschmidt (2020). For an important overview of Wittgenstein's quietism, see McDowell (2009).

19 Perhaps even more so. See Pritchard (2019a; 2019b; forthcomingb).

20 Relatedly, it is also a sceptical solution in the sense of claiming that a body of everyday claims that we are optimally certain of are in fact not only unknown but unknowable.

21 See Ribeiro (2009) for a useful critical overview of Montaigne's appeal to custom in this regard.

22 This is part of the fourfold regimen that Sextus offers which preserves the skeptic's ability to live in the world:

"Thus, attending to what is apparent, we live in accordance with everyday observances, without holding opinions-for we are not able to be utterly inactive. These everyday observances seem to be fourfold, and to consist in guidance by nature, necessitation by feelings, handing down of laws and customs, and teachings of kinds of expertise. By nature's guidance we are naturally capable of perceiving and thinking. By the necessitation of feelings, hunger conducts us to food and thirst to drink. By the handing down of customs and laws, we accept, from an everyday point of view, that piety is good and impiety bad. By teaching of kinds of expertise we are not inactive in those of them which we accept. And we say all this 
without holding any opinions." (PH I 23-24;

translation Annas \& Barnes 2000)

See, however, the remarks in endnote 3.

(cc) BY

Manuscrito - Rev. Int. Fil. Campinas, v. 44, n. 4, pp. 03-30, Oct.-Dec. 2021. 